\title{
PENGARUH FLAVANOID DALAM EKSTRAK MENTIMUN (Cucumis sativus $L$ ) TERHADAP KADAR KOLESTEROL TOTAL DARAH MENCIT (Mus musculus $L$ ) YANG MENGKONSUMSI MAKANAN CEPAT SAJI
}

\author{
Hetti Rusmini ${ }^{1}$, Dwi Marlina², Putri Lestari ${ }^{3}$ \\ ${ }^{1}$ Departemen Farmakologi, Fakultas Kedokteran, Universitas Malahayati \\ ${ }^{2}$ Departemen Kimia Medik, Fakultas Kedokteran, Universitas Malahayati \\ ${ }^{3}$ Program Studi Kedokteran, Fakultas Kedokteran, Universitas Malahayati
}

\begin{abstract}
The Effect of Flavanoid in Cucumber (Cucumis Sativus L) Extract On Total Cholesterol Levels Of Mice (Mus Musculus L) Consuming Fast Food Hypercholesterolemia is a condition cholesterol rate in blood more than $240 \mathrm{mg} / \mathrm{dl}$ that cause cardiovascular disease and it has position as a first level which can cause death in the world. Flavanoid is a substance of cucumber which can decrease cholesterol rate by blocking enzyme HMG KoA reductase activity and act as cofactor enzyme cholesterol esterase and cofactor enzyme cholesterol esterase and inhibition cholesterol absorbtion. The objective is to know the flavanoid effect of cucumber extraction for decreasing cholesterol rate of mice that consume fast food. This study use true experiment and pre \& post test control group design. The result in this study is cholesterol rate on mice before consume flavanoid by cucumber extraction with dose P1 $=126,8 \mathrm{mg} / \mathrm{dl}$, dose P2 $=140 \mathrm{mg} / \mathrm{dl}$, dose P3 $=146,8 \mathrm{mg} / \mathrm{dl}$ and after consume flavanoid by cucumber extraction with dose $\mathrm{P} 1=85,8 \mathrm{mg} / \mathrm{dl}$, dose $\mathrm{P} 2=67,8 \mathrm{mg} / \mathrm{dl}$, dose $\mathrm{P} 3=23,8 \mathrm{mg} / \mathrm{dl}$. There is a significant effection, a lot of flavanoid dose number from cucumber extraction can decrease a cholesterol rate in blood who consume fast food.
\end{abstract}

Keyword: Cholesterol, cucumber, mice, flavanoid, fast food, extraction

Abstrak: Pengaruh Flavanoid Dalam Ekstrak Mentimun (Cucumis Sativus $L$ ) Terhadap Kadar Kolesterol Total Darah Mencit (Mus Musculus L) yang Mengkonsumsi Makanan Cepat Saji. Hiperkolesterolemia adalah kondisi kadar kolesterol dalam darah melebihi $240 \mathrm{mg} / \mathrm{dl}$ yang merupakan salah satu penyebab penyakit kardiovaskular yang berada di peringkat pertama sebagai penyebab kematian di dunia. Flavanoid adalah senyawa yang terdapat dalam mentimun yang dapat menurunkan kolesterol total darah dengan cara menghambat aktivitas enzim HMG KoA reduktase dan bertindak sebagai kofaktor enzim kolesterol esterase dan inhibitor absorbsi kolesterol. Tujuan penelitian ini adalah untuk mengetahui pengaruh konsumsi flavanoid dalam ekstrak mentimun terhadap kadar kolesterol total darah yang mengkonsumsi makanan cepat saji. Metode Penelitian ini merupakan eksperiment murni menggunakan pre \& post test control group design. Hasil yang didapatkan pada penelitian ini adalah nilai kolesterol total darah mencit sebelum diberikan flavanoid dalam ekstrak mentimun dengan dosis $\mathrm{P} 1=126,8$ $\mathrm{mg} / \mathrm{dl}$, dosis P2 $=140 \mathrm{mg} / \mathrm{dl}$, dosis $\mathrm{P} 3=146,8 \mathrm{mg} / \mathrm{dl}$ dan setelah diberikan flavanoid dalam ekstrak mentimun dengan dosis $\mathrm{P} 1=85,8 \mathrm{mg} / \mathrm{dl}$, dosis $\mathrm{P} 2=67,8$ $\mathrm{mg} / \mathrm{dl}, \mathrm{P} 3=23,8 \mathrm{mg} / \mathrm{dl}$. Terdapat pengaruh, semakin besar dosis flavanoid dalam ekstrak mentimun yang diberikan semakin besar pula penurunan kadar kolesterol total darah yang mengkonsumsi.

Kata kunci: kolesterol, mentimun, mencit, flavanoid, makanan cepat saji. 


\section{PENDAHULUAN}

Kolesterol merupakan senyawa yang berbentuk lunak, seperti lilin. (Firdiansyah, 2014; Dhesti A P dkk, 2014). Kadar normal kolesterol total dalam darah seharusnya $<240 \mathrm{mg} / \mathrm{dl}$, apabila jumlah kadar kolesterol total dalam darah melebihi nilai normal maka tubuh akan mengalami kondisi hiperkolesterolemia. Menurut Setyaji dalam penelitiannya kondisi hiperkolesterolemia dapat menimbulkan kondisi aterosklerosis dan kejadian kardiovaskular (Setyaji D Y, 2011). Dalam Vanessa dkk pada tahun 2014 juga mengatakan bahwa terjadinya aterosklerosis dapat menyebabkan terjadinya penyakit kardiovaskular (Vanessa dkk, 2014). Begitu pula dalam penelitian Sunaryo dkk pada tahun 2014 yang mengatakan bahwa hiperglikemi, hiperkolesterolemia dan oksidasi LDL yang telah terbukti dalam berbagai penelitian bahwa hal tersebut merupakan penyebab utama terjadinya aterosklerosis dan penyakit kardiovaskular (Sunaryo dkk, 2014). Hal tersebut dapat menjelaskan keterkaitan keadaan hiperkolesterolemia terhadap resiko kejadian penyakit kardiovaskular. The American Heart Association tahun 2015 mencatat, angka kematian no 1 di dunia disebabkan oleh penyakit kardiovaskular. Sekitar 17,3 miliar orang pertahun yang mati akibat penyakit kardiovaskular. Angka tersebut di ekspektasikan akan mencapai 23,6 miliar orang pada tahun 2030. (The American Heart Association,2015). Di samping itu data kementerian kesehatan RI pada tahun 2014, menyatakan bahwa penderita penyakit jantung koroner di Indonesia tahun 2014 sebesar 0,5\% atau diperkirakan sekitar 883,447 orang. Sedangkan penderita penyakit jantung koroner di provinsi lampung adalah sebesar $0,2 \%$ atau diperkirakan sekitar 11.121 orang
(Kemenkes RI, 2014). Adapun hal-hal yang dapat mempengaruhi jumlah kadar kolesterol darah, salah satunya konsumsi makanan cepat saji yang berlebihan.

Beberapa penelitian menggunakan survey masyarakat berdasarkan frekuensi konsumsinya dalam penelitian Putri pada tahun 2014 dan Aisya tahun 2015, menyampaikan bahwa makanan cepat saji yang paling sering dikonsumsi subjek penelitiannya adalah fried chicken (Putri L N, 2014; Aisya, 2015). Adapun tujuan dari penatalaksanaan hiperkolesterolemia adalah untuk menurunkan resiko terjadinya penyakit jantung. Penanganan ini dilakukan dengan cara meningkatkan aktivitas fisik dengan berolahraga secara teratur dan juga mengatur jenis makanan yang dikonsumsi (Elon $Y$ dkk, 2015). Makanan yang dapat dijadikan upaya untuk mencegah meningkatnya kadar kolesterol total darah yaitu memilih makanan yang mengandung senyawa-senyawa yang dapat mempertahankan kadar kolesterol total darah dalam batas normal (Rosyada F M, 2013). Back to nature merupakan tren masyarakat dunia saat ini yang menjadi pilihan dalam memilih makanan yang berasal dari alam yang juga dapat berperan sebagai pengobatan, bersifat aman dan telah digunakan oleh nenek moyang secara turun temurun (Fitriani, 2013).

Mentimun (Cucumis sativus $L$ ) merupakan salah satu jenis sayuran yang juga dapat dijadikan sebagai bahan obat- obatan (Abdurrazak dkk, 2013). Dengan mengkonsumsi mentimun dapat menurunkan tekanan darah dan flavanoidnya dapat menghalangi reaksi oksidasi LDL yang dapat menyebabkan aterosklerosis (Syaifuddin, 2013). Dalam penelitian 
Nugroho juga mengatakan bahwa mentimun juga memiliki kandungan flavanoid dan saponin (Nugroho, 2015) yang berperan dalam menurunkan kadar kolesterol darah dengan cara menurunkan penyerapan kolesterol dan asam empedu pada usus halus sehingga menyebabkan peningkatan ekskresi lewat feses (Harjana, 2011).

Tujuan penelitian ini adalah untuk mengetahui pengaruh konsumsi flavanoid dalam ekstrak mentimun terhadap kadar kolesterol total darah mencit yang mengkonsumsi makanan cepat saji.

\section{METODE}

Jenis penelitian dalam penelitian ini adalah eksperiment murni (True-experiment) dengan penelitian laboratorium dan menggunakan pre \& post test control group design. Penelitian ini dilakukan di Dinas Peternakan dan Kesehatan Hewan pemerintah provinsi Lampung, dan Laboratorium FMIPA Universitas Lampung. Penelitian ini akan dilakukan selama bulan Febuari-Maret tahun 2017. Populasi yang digunakan dalam penelitian ini adalah mencit jenis Mus musculus sebanyak kurang lebih 250 ekor. Akan tetapi, sampel diambil berdasarkan rumus Federer sesuai perlakuan. Sampel pada penelitian diambil dengan menggunakan teknik purposive sampling. Sampel yang digunakan dalam penelitian ini adalah mencit jantan jenis Mus musculus. Umur mencit 8 minggu dengan berat badan 20-30 gram dan dalam keadaan sehat, normal sebanyak 25 ekor.

Sampel kontrol pada penelitian dibagi menjadi 2 kelompok, masingmasing kelompok terdiri dari 5 ekor mencit yang dimasukkan dalam kandang terpisah. 1. Kelompok kontrol (K (-)) diberikan pakan standar berupa makanan khusus untuk pakan mencit jenis Mus musculus, 2. kelompok pakan hiperkolesterol diberikan pakan fried chicken $(\mathrm{KF}(-)) . \quad(\mathrm{K}(-))$ diberikan pakan standard yang diberikan satu kali sehari kepada masing-masing mencit. $(\mathrm{KF}(-))$ diberikan pakan hiperkolesterol berupa fried chicken yang dihaluskan sebanyak 34,6 gram fried chicken perhari yang diberikan satu kali sehari kepada 1 ekor mencit. Sampel perlakuan pada penelitian ini dibagi menjadi 3 kelompok. Masingmasing kelompok yang sudah hiperkolesterolemia diberikan ekstrak mentimun.

Dosis dalam penelitian ini didapatkan menggunakan penelitian pre-eksperimen. Sehingga pemberian dosis makanan cepat saji untuk 1 ekor mencit; 34,6 gram fried chicken/hari dan dosis flavanoid dalam ekstrak mentimun adalah Dosis $\mathrm{P} 1=0,02 \mathrm{mg} / 20 \mathrm{~g}$ BB /hari, Dosis P2 $=0,2 \mathrm{mg} / 20 \mathrm{~g} \mathrm{BB} /$ hari, Dosis P3 = $2 \mathrm{mg} / 20 \mathrm{~g} B B /$ hari.

\section{Alat Percobaan}

Kandang mencit, penutup kandang, handscoon, masker, botol air minum mencit, pakan mencit standar, aquades untuk minum, mangkuk kecil, sendok, Blander, seperangkat alat gelas, kertas saring, evaporator, sonde, neraca analitik, penguap putar vakum, tabung reaksi, pipet tetes, pelat tetes, batang pengaduk, Alat cek kolesterol merk "easy touch", Strip kolesterol merk easy touch, Spuit, Kapas kering, Kapas alcohol.

\section{Bahan Percobaan}

Fried chicken, Buah mentimun, Methanol, n-heksan, Etil asetat, Aquadest, $\mathrm{Mg}-\mathrm{HCl}, \mathrm{H} 2 \mathrm{SO} 4$ pekat, $\mathrm{NaOH}$ pekat, Silica gel GF254, Plat KLT, (Megawati R C, 2014).

\section{Prosedur pembuatan ekstrak mentimun}

Pembuatan ekstrak mentimun adalah sebagai berikut:

1) Pemilihan mentimun, mentimun yang digunakan dalam penelitian 
ini adalah mentimun jenis biasa sebanyak $1 \mathrm{~kg}$

2) Buah dicuci sampai bersih menggunakan larutan garam

3) Bilas air menggunakan air mengalir Iris sangat tipis mentimun

4) Keringkan mentimun tersebut selama +2 hari dengan di anginanginkan dalam suhu ruangan dan dijauhkan dari cahaya matahari langsung

5) Lalu mentimun yang telah cukup hilang kadar airnya direndam atau dimaserasi didalam metanol $96 \%$ selama kurang lebih $3 \times 24$ jam

6) Setiap $1 \times 24$ jam hasil maserasi (maserat) disaring dan ditampung dalam Erlenmeyer dan mentimun tersebut kembali dimaserasi dengan methanol yang baru

7) Maserat yang diperoleh dipekatkan dengan penguap putar vakum pada suhu 30-450C, sehingga diperoleh ekstrak kental methanol (Puspitasari L, 2015).

\section{Prosedur mengisolasi \\ mengidentifikasi flavanoid}

Setelah dilakukan evaporasi ekstrak kentak methanol di isolasi dengan prosedur sebagai berikut:

1. Ekstrak tersebut disuspensikan ke dalam campuran pelarut $\mathrm{MeOH}-$ dan $\mathrm{H} 2 \mathrm{O}$ (2:1) kemudian dipartisi secara berulang-ulang dengan $\mathrm{n}$ heksan, etil asetat sehingga diperoleh masing-masing partisi dari fraksi tersebut

2. Hasil partisi dari fraksi-fraksi tersebut dievaporasi pada suhu 30-450C sampai diperoleh ekstrak kental n-heksan, ekstrak kental etil asetat, dan ekstrak air

3. Masing-masing ekstrak kental yang diperoleh (ekstrak kental methanol, ekstrak kental nheksan, ekstrak kental etil asetat dan ekstrak air) dilanjutkan dengan melakukan uji fitokimia (Megawati R C, 2014)

4. Isolate murni diidentifikasi sebanyak 0,25 mg dimasukkan ke dalam tabung reaksi, lalu ditambahkan 2,5 $\mathrm{ml}$ methanol dan 2,5 $\mathrm{ml}$ aquades

5. Setelah itu dilakukan pemanasan diatas api +5 menit, lalu di tambahkan $\mathrm{NaOH}$ pekat sebanyak 2 tetes (Mulyani S, Dkk, 2011)

6. Interpretasi

\section{Pemeriksaan kolesterol}

Pemeriksaan

kolesterol diperiksa secara langsung dengan mengunakan alat cek kolesterol merk "easy touch". Darah yang diambil sebanyak $0,05 \mathrm{ml}$ setiap satu kali pengambilan pada 1 ekor mencit. Darah diambil di pembuluh darah perifer dibagian ekor mencit dengan melukai sedikit menggunakan jarum kecil dan steril.

\section{HASIL}

Dalam penelitian ini terdapat kriteria yang harus dipenuhi. Data dan karakteristik penelitian ini disajikan dalam tabel dibawah ini:

Tabel 1. Karakteristik Mencit

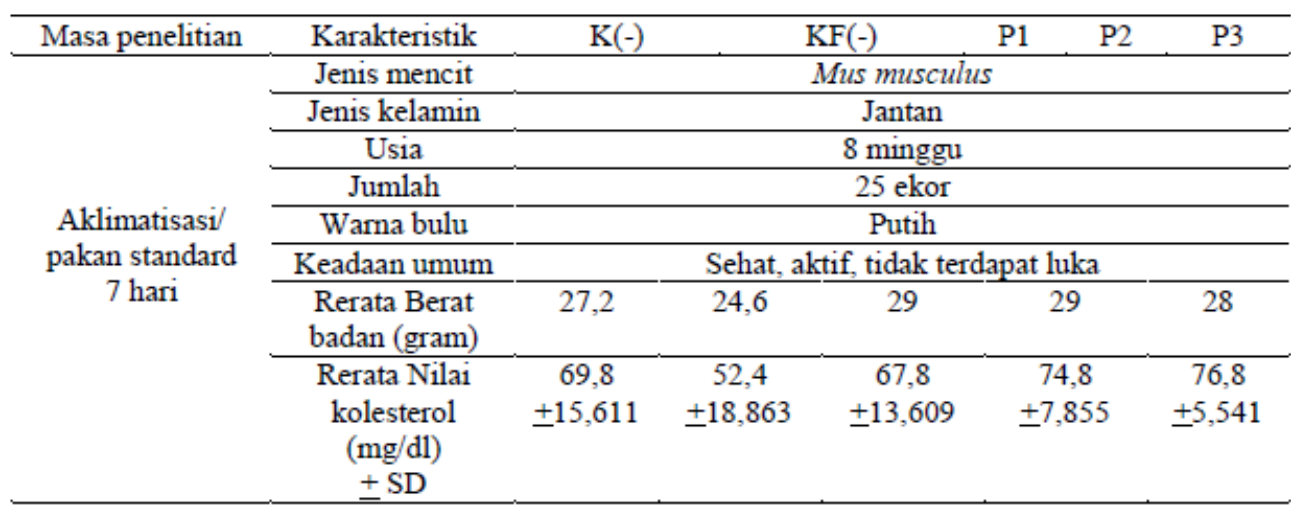




\begin{tabular}{|c|c|c|c|c|c|c|}
\hline \multirow{4}{*}{$\begin{array}{c}\text { Pemberian pakan } \\
\text { hiperkoleste } \\
\text { rolemia } \\
\text { (fried chicken } \\
34,6 \text { gram) } \\
7 \text { hari }\end{array}$} & Warna bulu & \multicolumn{5}{|c|}{ Putih } \\
\hline & Keadaan umum & \multicolumn{5}{|c|}{ Sehat, aktif, tidak terdapat luka } \\
\hline & $\begin{array}{c}\text { Rerata Berat } \\
\text { badan (gram) }\end{array}$ & 30,2 & 32 & 36 & 32,8 & 32,2 \\
\hline & $\begin{array}{c}\text { Rerata Nilai } \\
\text { kolesterol } \\
(\mathrm{mg} / \mathrm{dl}) \\
+\mathrm{SD}\end{array}$ & $\begin{array}{c}71,2 \\
+15,385\end{array}$ & $\begin{array}{c}127 \\
+23,270\end{array}$ & $\begin{array}{c}126,8 \\
+13,293\end{array}$ & $\begin{array}{c}140 \\
+14,124\end{array}$ & $\begin{array}{r}146,8 \\
+10,986\end{array}$ \\
\hline \multirow{5}{*}{$\begin{array}{c}\text { Setelah diberikan } \\
\text { ekstrak flavanoid } \\
14 \text { hari }\end{array}$} & Warna bulu & \multicolumn{5}{|c|}{ Putih } \\
\hline & Keadaan umum & $\begin{array}{c}\text { Sehat, aktif, } \\
\text { tidak } \\
\text { terdapat luka }\end{array}$ & \multicolumn{2}{|c|}{$\begin{array}{c}\text { Kurang aktif, } \\
\text { sedikit } \\
\text { lemas, tidak } \\
\text { terdapat luka }\end{array}$} & $\begin{array}{c}\text { aktif, tida } \\
\text { luka }\end{array}$ & erdapat \\
\hline & $\begin{array}{l}\text { Rerata Berat } \\
\text { badan (gram) }\end{array}$ & 31,6 & 39,6 & 31,2 & 23 & 23,4 \\
\hline & Rerata Nilai & 73,2 & 275 & 85,8 & 67,8 & 23,8 \\
\hline & $\begin{array}{c}\text { kolesterol } \\
(\mathrm{mg} / \mathrm{dl}) \\
+\mathrm{SD}\end{array}$ & $\pm 14,856$ & $\pm 22,782$ & $\pm 14,132$ & $\pm 12,872$ & $\pm 1,924$ \\
\hline
\end{tabular}

Keterangan:

$\mathrm{K}(-)$ : Kelompok kontrol yang hanya diberikan pakan standard

$\mathrm{K}(+)$ : Kelompok kontrol yang hanya diberikan pakan fried chicken

P1 : Kelompok perlakuan yang diberikan flavanoid dalam ekstrak mentimun sebanyak $0,02 \mathrm{mg} / 20 \mathrm{gBB} /$ hari dan fried chicken

P2 : Kelompok perlakuan yang diberikan flavanoid dalam ekstrak mentimun sebanyak 0,2mg/20gBB/hari dan fried chicken

P3 : Kelompok perlakuan yang diberikan flavanoid dalam ekstrak mentimun sebanyak $2 \mathrm{mg} / 20 \mathrm{gBB} / /$ hari dan fried chicken

Berdasarkan tabel diatas didapatkan perbedaan rerata kadar kolesterol total darah pada mencit Mus musculus jantan setelah diberikan pakan fried chicken. Nilai rerata kolesterol total darah mencit yang diberikan pakan standard selama 7 hari pada $\mathrm{K}(-)=69,8$ $\mathrm{mg} / \mathrm{dl}$, pada $\mathrm{KF}(-)=52,4 \mathrm{mg} / \mathrm{dl}$, pada $\mathrm{P} 1=67,8 \mathrm{mg} / \mathrm{dl}$, pada $\mathrm{P} 2=74,8$ $\mathrm{mg} / \mathrm{dl}$, dan pada $\mathrm{P3}=76,8 \mathrm{mg} / \mathrm{dl}$. Sedangkan rerata kadar kolesterol total darah mencit setelah pemberian pakan fried chicken selama 7 hari pada $\mathrm{K}(-)=71,2 \mathrm{mg} / \mathrm{dl}$, pada $\mathrm{KF}(-)=$ $127 \mathrm{mg} / \mathrm{dl}$, pada $\mathrm{P} 1=126,8 \mathrm{mg} / \mathrm{dl}$, pada $\mathrm{P} 2=140 \mathrm{mg} / \mathrm{dl}$, dan pada $\mathrm{P} 3=$ $146,8 \mathrm{mg} / \mathrm{dl}$. Pemberian paparan fried chicken dan flavanoid terhadap kadar kolesterol total darah mencit juga terdapat pengaruh yang cukup besar. Mencit diberikan paparan flavanoid dengan dosis $\mathrm{P} 1=0,02 \mathrm{mg}$, dosis $\mathrm{P} 2$ $=0,2 \mathrm{mg}$, dosis $\mathrm{P} 2=2 \mathrm{mg}$ selama 14 hari. Dari ke tiga perlakuan tersebut didapatkan penurunan kadar kolesterol total darah mencit yang terendah adalah mencit yang diberikan flavanoid dosis $\mathrm{P} 1=0,02$ $\mathrm{mg}$ yaitu $73,2 \mathrm{mg} / \mathrm{dl}$. Sedangkan, penurunan kadar kolesterol total darah mencit tertinggi adalah mencit yang diberikan flavanoid dosis P3 $=2$ $\mathrm{mg}$ yaitu 23,8 mg/dl. Sehingga berdasarkan tabel diatas menunjukkan bahwa semakin besar dosis flavanoid yang diberikan, maka semakin besar penurunan kadar kolesterol total darah mencit.

Dari hasil tersebut kemudian data ketiga perlakuan yang diperoleh dianalisis secara statistik menggunakan program SPSS. Distribusi data diuji dengan menggunakan uji statistic Shapiro Wilk. Didapatkan hasil sebagai berikut $\mathrm{K}(-) ; p=0,453, \mathrm{KF}(-) ; p=0,094$, $\mathrm{P} 1 ; p=0,128, \mathrm{P} 2 ; p=0,536, \mathrm{P} 3 ; p$ $=0,928$, yang berarti nilai kolesterol 
total mencit ke lima kelompok terdistribusi normal $(p>0,05)$.

Selanjutnya data kelima kelompok tersebut diuji menggunakan Oneway-annova. Sebelum diuji Oneway-annova, data di uji homogeinitas variansnya menggunakan levene test. Hasil yang didapatkan pada uji levene $p=0,146$ dengan $(p>0,05)$ berarti tidak terdapat perbedaan varians antara kelompok data atau varians data normal. Karena distribusi dan homogeinitas varians data normal maka selanjutnya data tersebut dapat dilakukan uji Oneway-annova. Pada uji Oneway-annova didapatkan $p=$ $0,000 \quad(p<0,05)$ yang berarti terdapat perbedaan yang bermakna antar kelompok perlakuan. Setelah dilakukan uji Oneway-annova, dilakukan uji post hoc tukey untuk mengetahui antar kelompok manakah yang mengalami perbedaan signifikan. Hasil uji post hoc tukey disajikan pada histogram dibawah ini:

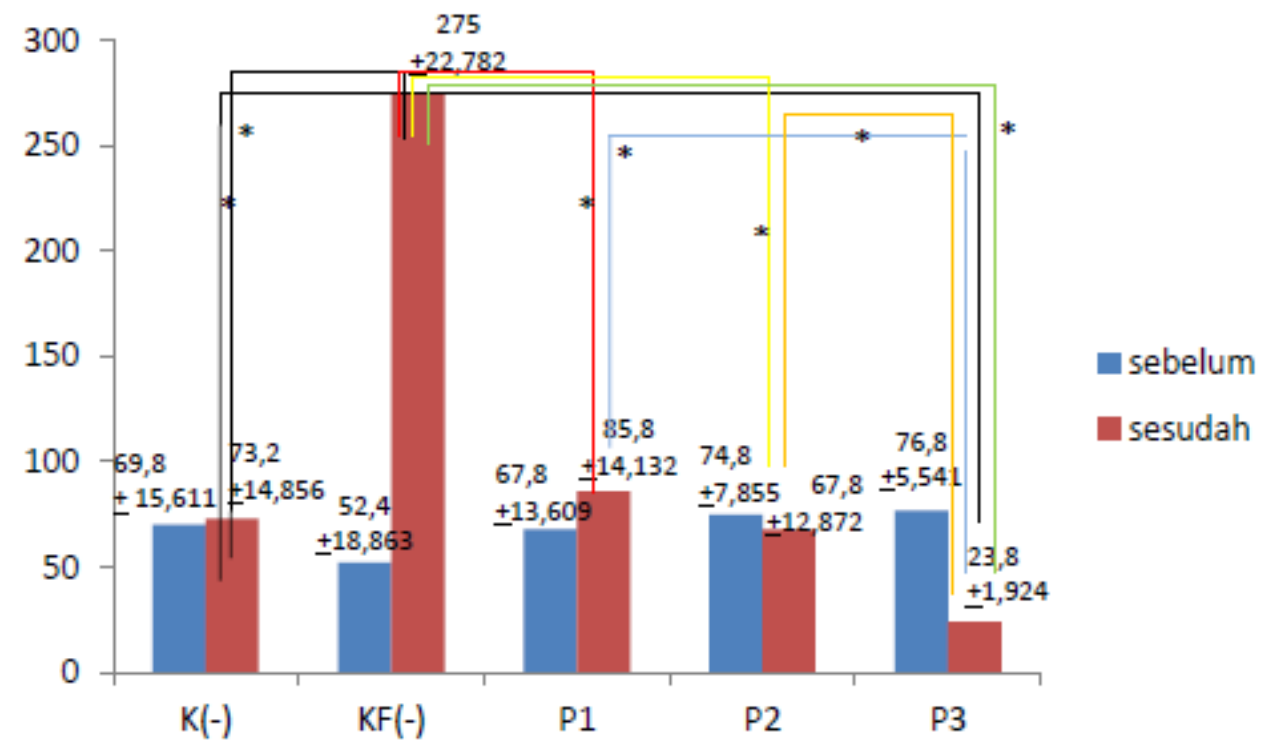

\section{Gambar 1. Analisis post hoc tuckey flavonoid dalam ekstrak mentimun terhadap kolesterol}

P1 : Kelompok perlakuan yang diberikan flavanoid dalam ekstrak mentimun sebanyak $0,02 \mathrm{mg} / 20 \mathrm{gBB} /$ hari dan fried chicken

P2 : Kelompok perlakuan yang diberikan flavanoid dalam ekstrak mentimun sebanyak 0,2mg/20gBB/hari dan fried chicken

P3 : Kelompok perlakuan yang diberikan flavanoid dalam ekstrak mentimun sebanyak $2 \mathrm{mg} / 20 \mathrm{gBB} / /$ hari dan fried chicken

* : Menunjukkan data rerata penurunan kolesterol yang paling signifikan.

Dari uji tukey didapatkan hasil penurunan nilai kolesterol total pada mencit yang paling berarti adalah $\mathrm{P} 1$ dengan $\mathrm{P} 3$ dan $\mathrm{P} 2$ dengan $\mathrm{P} 3 . \mathrm{K}(-)$ dengan $\mathrm{KF}(-) ; p=0,000, \mathrm{~K}(-)$

\section{PEMBAHASAN}

Berdasarkan penelitian yang telah dilakukan terhadap kolesterol total darah mencit menunjukkan hasil dengan $\mathrm{P} 3 ; p=0,000, \mathrm{KF}(-)$ dengan $\mathrm{P} 1 ; p=0,000, \mathrm{KF}(-)$ dengan $\mathrm{P} 2 ; p=$ $0,000, \mathrm{KF}(-)$ dengan P3; $p=0,000$, $\mathrm{P} 1$ dengan $\mathrm{P} 3 ; p=0,000, \mathrm{P} 2$ dengan P3; $p=0,001(P<0,05)$.

yang bervariasi. Walaupun demikian nilai kolesterol total darah mencit mengalami penurunan setelah 
mengkonsumsi flavanoid dalam ekstrak mentimun setelah mengalami hiperkolesterolemia akibat konsumsi makanan cepat saji sebagai makanan yang mengandung lemak jenuh. Konsumsi makanan cepat saji menurut penelitian Suswanti tahun 2012 dapat meningkatkan kejadian hiperkolesterol dan gangguan kardiovascular (Suswanti, 2012). Karena kandungan makanan cepat saji pada umumnya memiliki kandungan tinggi lemak, tinggi natrium, tambahan bahan makanan, tinggi kalori, gula, dan natrium tetapi rendah serat, vitamin $A$, kalsium dan folat (Suswanti, 2012; Putri L N, 2014). Dalam penelitian Suswanti tahun 2012 mengatakan bahwa mengkonsumsi makanan cepat saji dapat meningkatkan kejadian hiperkolesterol, obesitas, dislipidemia dan mendukung resiko terjadinya stroke dan gangguan kardiovascular, kanker bahkan kematian (Suswanti, 2012). Oleh sebab itu, konsumsi makanan cepat saji harus dikurangi dan mengatur jenis makanan yang dikonsumsi.

Obat-obatan yang diberikan pada penderita hiperkolesterolemia adalah obat hipolipidemik, akan tetapi konsumsi obat tersebut memiliki efek samping seperti myophaty (Elon $\mathrm{Y}$ dkk, 2015). Makanan yang dapat dijadikan upaya untuk mencegah meningkatnya kadar kolesterol total darah yaitu memilih makanan yang rendah lemak jenuh, rendah kolesterol, serta mengkonsumsi makan-makanan yang mengandung senyawa-senyawa yang dapat mempertahankan kadar kolesterol total darah dalam batas normal (Rosyada F M, 2013). Back to nature merupakan tren masyarakat dunia saat ini yang menjadi pilihan dalam memilih makanan. Masyarakat saat ini lebih memilih mengkonsumsi makanan yang berasal dari alam yang juga dapat berperan sebagai pengobatan, bersifat aman dan telah digunakan oleh nenek moyang secara turun temurun (Fitriani, 2013). Makanan dari alam salah satunya adalah buah mentimun yang telah diteliti kandungan-kandungannya yang sangat bermanfaat bagi tubuh.

Mentimun (Cucumis sativus $L$ ) merupakan family tumbuh-tumbuhan yang dapat dikonsumsi segar dan memiliki banyak kandungan yang berpotensi menurunkan kadar kolesterol total darah. Salah satunya adalah senyawa flavanoid yang dapat berperan sebagai antioksidan untuk menangkal radikal bebas, memperbaiki pembuluh darah yang rusak dan mempertahankan kadar kolesterol dalam batas normal. Berdasarkan penelitian Rosyada S M pada tahun 2013 pada penelitiannya menyampaikan bahwa flavanoid dapat menurunkan kolesterol total darah dengan cara menghambat aktivitas enzim HMG KoA reduktase yang berperan penting dalam proses biosintesis kolesterol. Flavanoid juga bertindak sebagai kofaktor enzim kolesterol esterase dan inhibitor absorbsi kolesterol pada makanan dengan menghambat pembentukan misel (Rosyada S M, 2013).

Dalam penelitian Vanessa dkk juga mengatakan bahwa flavanoid dapat mengurangi resiko tingginya jumlah kolesterol dalam darah (Vanessa dkk, 2014) dengan cara meningkatkan produksi apo A1 yang menyebabkan meningkatnya produksi HDL sehingga pengangkutan kolesterol yang tidak digunakan oleh tubuh meningkat dan tidak terjadi kondisi hiperkolesterolemia (Kusumastuty I, 2014). Selain itu, flavanoid juga meningkatkan ekskresi asam empedu untuk dijadikan energi serta menurunkan penyerapan kolesterol dan asam empedu kembali 
dalam usus halus sehingga terjadi peningkatan ekskresi kolesterol dan asam empedu melalui feces. Oleh sebab itu kolesterol yang beredar dalam darah tidak melebihi batas normal sehingga membantu menghalangi proses terjadinya oksidasi LDL dan mencegah LDL teroksidasi menempel pada sel endotel yang cedera. Sel endotel yang cedera juga akan diperbaiki oleh flavanoid dengan cara berperan sebagai antioksidan yang dapat menangkap radikal bebas sehingga mencegah proses inflamasi dan mengurangi resiko kejadian aterosklerosis (Harjana, 2011; Syaifuddin, 2013).

Penelitian lain yang dilakukan oleh Syaifuddin pada tahun 2013 juga menyampaikan bahwa mentimun memiliki kandungan flavanoid yang dapat menghalangi reaksi oksidasi Low Density Lipoprotein (LDL) dengan bertindak sebagai antioksidan dan mencegah pengendapan LDL yang teroksidasi pada sel endotel (Syaifuddin, 2013).

Dengan demikian dari hasil penelitian ini menunjukkan bahwa flavanoid dalam ekstrak mentimun besar pengaruhnya dalam menurunkan kadar kolesterol total darah mencit Mus musculus jantan yang hiperkolesterolemia setelah mengkonsumsi makanan cepat saji.

\section{KESIMPULAN}

Berdasarkan hasil penelitian ini, maka dapat disimpulkan bahwa kandungan senyawa flavanoid dalam ekstrak mentimun (Cucumis sativus) terhadap kadar kolesterol total darah:

1. Terdapat nilai kadar kolesterol total darah mencit sebelum mengkonsumsi makanan cepat saji yaitu sebesar $68,32 \mathrm{mg} / \mathrm{dl}$ dan sesudah mengkonsumsi makanan cepat saji yaitu sebesar 122,36 mg/dl. Hal ini membuktikan peningkatan kadar kolesterol kurang lebih dua kali lipat.

2. Terdapat nilai kadar kolesterol total darah mencit sebelum diberikan treatment flavanoid dalam ekstrak mentimun dengan dosis $0,02 \mathrm{mg}=126,8$ $\mathrm{mg} / \mathrm{dl}$, dosis $0,2 \mathrm{mg}=140$ $\mathrm{mg} / \mathrm{dl}$, dosis $2 \mathrm{mg}=146,8$ $\mathrm{mg} / \mathrm{dl}$ dan sesudah diberikan treatment pemberian flavanoid dalam ekstrak mentimun dengan dosis $0,02 \mathrm{mg}=85,8$ $\mathrm{mg} / \mathrm{dl}$, dosis $0,2 \mathrm{mg}=67,8$ $\mathrm{mg} / \mathrm{dl}$, dosis $2 \mathrm{mg}=23,8$ $\mathrm{mg} / \mathrm{dl}$.

3. Terdapat pengaruh pemberian flavanoid dalam ekstrak mentimun terhadap penurunan kadar kolesterol total darah mencit yang mengalami hiperkolesterolemia.

\section{Daftar Pustaka}

Abdurazzak, Hatta, M., \& Marliah, A. (2013). pertumbuhan dan hasil tanaman mentimun (Cucumis sativus L) akibat perbedaan jarak tanam dan Jumlah Benih Per Lubang Tanam. 55-59.

Aisya, R. W. (2015). Hubungan Kebiasaan Konsumsi Makanan Cepat Saji Dengan Kejadian Penyakit Jantung Koroner Pada Pasien Rawat Jalan Di RSUD dr. Moewardi. 1-10.

Aurora, R. G., Sinambela, A., \& Noviyanti, C. H. (2012). Peran konseling berkelanjutan pada penanganan pasien hiperkolesterolemia. artikel pengembangan pendidikan keprofesian berkelanjutan (P2KB) , 194-200.

Darlina, Rahardjo, T., \& Nurhayati, S. (2011, november 16). Perubahan Jenis Leukosit Pada Mencit Yang Di Imunisasi 
Dengan Plasmodium Berghei Yang Di Radiasi. 434-439.

Dhesti, A. P., \& Widyaningsih, T. D. (2014). pengaruh pemberian liang teh berbasis cincau hitam (Mesona palustris $\mathrm{BL}$ ) terhadap kadar kolesterol tikus wistar. jurnal pangan dan agroindustri, 2 (2), 103-109.

Easy, touch. GCU Blood Glucose, Cholesterol, Uric Acid Multifunction Monitoring System.

Ekananda, N. (2015). Bay leaf in dyslipidemia therapy. 4 (4), 64-68.

Elon, Y., \& Polancos, J. (2015). Manfaat jeruk nipis (Citrus aurantifolia) dan olahraga untuk menurunkan kolesterol total klien dewasa. jurnal skolastik keperawatan, 1 (2), 148-153.

Firdiansyah, M. H. (2014). Hubungan Antara Rasi kadar kolesterol total terhadap High-Density Lipoprotein (HDL) dengan kejadian penyakit jantung koroner di RSUD dr Moewardi. 5-18.

Fitriani, T. D. (2013). efektifitas temulawak dalam menurunkan tekanan darah pada lansia di upt panti social tresna werdha mulia dharma kabupaten kubu raya. $1-4$

Harjana, T. (2011). kajian tentang potensi bahan-bahan alami untuk menurunkan kadar kolesterol darah. prosiding seminar nasional penelitian pendidikan dan penerapan MIPA (pp. 1-5). Yogyakarta: fakultas MIPA universitas negeri yogyakarta.

Haryanto, A., \& Sayogo, S. (2013). Bagaimana peran hesperidin. hiperkolesterolemia, 40 (1), 13-15.

Hermawan, A. (2015). Kajian Sifat Fisik Buah Mentimun (Cucumis sativus L) menggunakan pengolahan citra (image processing).
Jempormase, F., Bodhi, W., \& Kepel, B. J. (2016, januari-juni). Prevalensi hiiperkolesterolemia pada remaja obes di kabupaten minahasa. jurnal ebiomedik $(\mathrm{eBm}), 4$. bagian kimia fakultas kedokteran universitas sam ratulangi.

Katzung, B. G., Master, S. B., \& Trevor, A. J. (2012). Farmakologi dasar dan klinik. EGC.

Kemenkes RI, k. k. (2014). Situasi Kesehatan Jantung. www.depkes.go.id.

Kusumastuty, I. (2014). Sari buah markisa ungu mencegah peningkatan MDA serum tikus dengan diet aterogenik. indonesia journal of human nutrition, 1 (1), 50-56.

McPhee, S. J., \& Ganong, W. F. (2006). Pengantar menuju kedokteran klinis. In d. F. Dany (Ed.), Buku patofisiologi penyakit (d. B. pendit, Trans., 5 ed., p. 339). EGC.

Megawati, R. C., Musa, W. J., \& Sihaloho, M. (2014). Isolasi dan Identifikasi senyawa flavanoid dalam ekstrak kental buah pare (Momordica charantia L). 1-3.

Mulyani S., Laksana T. (2011). Analisis Flavonoid Dan Tannin Dengan Metoda Mikroskopimikrokimiawi. 109114

Nugroho, A. M. (2015). pengaruh gel ekstrak dan serbuk mentimun (Cucumis sativus L) terhadap angiogenesis pada penyembuhan luka bakar derajat IIB pada tikus witar. 20-39.

Notoatmojo, S 2012, Metodologi Penelitian Kesehatan, edk 2, Rineka Cipta, Jakarta.

Octavia, S. k., Surdijati, S., \& Soegianto, L. (2015). Pengaruh pemberian infus kelopak kering rosella (Hibiscus sabdariffa) terhadap kadar kolesterol total serum 
darah

mencit

hiperkolesterolemia.

Price, S. A., \& Wilson, L. M. (2007). buku patofisiologi. In konsep klinis proses-proses penyakit (6 ed., pp. 857-858). EGC.

Puspitasari, I. (2015). Pengaruh Ekstrak dan Serbuk mentimun (Cucumis sativus L) terhadap jumlah makrofag pada penyembuhan luka bakar derajat IIB pada tikus wistar. 1-39.

Putri, L. N. (2014). Hubungan pola konsumsi fastfood dengan kejadian overweight pada remaja putri di SMA batik 1 surakarta. naskah publikasi, 4.

Redha, A. (2010). Flavanoid: Struktur, sifat antioksidatif dan peranannya dalam sistem biologis. jurnal berlian, 9 (2), 196-200.

Rosyada, S. M. (2013). Perbedaan pengaruh antara ekstrak dan rebusan daun salam (Eugenia polyantha) dalam pencegahan peningkatan kadar kolesterol total pada tikus sprague dawley. artikel penelitian, 515.

Setyaji, D. Y. (2011). pengaruh pemberian nata de coco terhadap kadar kolesterol LDL dan HDL pada tikus hiperkolesterolemia. 8.

Sumardika, I. W. (2012). ekstrak air daun ubi jalar ungu memperbaiki profil lipid dan menigkatkan kadar SOD darah tikus yang diberi makanan tinggi kolesterol. 43 (2), 6770.

Sunaryo, H., Siska, Dwiyanti, \& Arcinthya, R. (2014). kombinasi ekstrak etanol rimpang zingiber officinale roscoe dengan zn sebagai hipolipidemia pada mencit diabetik diet tinggi kolesterol. jurnal media farmasi, 11 (1), 64-72.

Susanti, N. M., Laksmiani, N. P., Warditiani, N. K., \& Sunariyani, P. E. (2015). Antiaterosklerosis andrografolid dari sambiloto melalui mekanisme antiinflamasi secara in silico. 8-11.

Suswanti, I. (2012). Faktor-faktor yang berhubungan dengan pemilihan makanan cepat sajii pada mahasiswa fakultas kedokteran dan ilmu kesehatan. 2-4.

Syaiffudin, M. (2013). penggunaan tanaman herbal pada lansia penderita hipertensi di kecamattan gatak kabupaten sukoharjo. 9.

The American Heart Association. (2015). heart disease and stroke statistics-at-a-glance "building healthier lives, free of cardiovascular disease and stroke. the american heart association.

Vanessa, R., Purwijantiningsih, L. M. \& Aida, Y. (2014) Pemanfaatan minuman serbuk instan kayu manis (Cinnamoun burmanii BI) untuk menurunkan kadar kolesterol total darah pada tikus putih (Rattus norvegicus). 1-14.

Widyaningrum, A. (2015). Pengaruh Perasan Daun Sambung Nyawa (Gynura procumbens (Lour) Merr.) Terhadap Kadar Kolesterol Mencit (Mus musculus L) Dan Pemanfaatannya Sebagai Karya Ilmiah Populer. 19-22. 